\title{
Economic Analysis of Groundnut Based Cropping Systems
}

\author{
D.P. Pacharne* and P.H. Deshmukh
}

Cotton Improvement Project, Mahatma Phule Krishi Vidyapeeth, Rahuri-413722 (M.S.), India

*Corresponding author

\section{A B S T R A C T}

\begin{tabular}{|l|}
\hline Ke y w o r d s \\
$\begin{array}{l}\text { Cropping systems, } \\
\text { Economic analysis, } \\
\text { Nutrient management, } \\
\text { Productivity and } \\
\text { Profitability }\end{array}$ \\
\hline Article Info \\
\hline $\begin{array}{l}\text { Accepted: } \\
\text { 20 August } 2018 \\
\text { Available Online: } \\
\text { 10 September } 2018\end{array}$ \\
\hline
\end{tabular}

\section{Introduction}

In recent years, stagnation in system productivity due to continuous cultivation of cereal-cereal cropping system, reduction in profitability and decline in soil health has been experienced. Inclusion of legume in a crop sequence not only takes care of soil health but also gives higher yield and economic returns to the farmers. In India, groundnut is essential and mostly adopted oilseed crop. The studies on different nutrient management treatments in kharif crops and its residual effects on rabi crops is necessary to increase yield and profitability of groundnut based cropping system. The targeted yield concept has also proved to be superior to others whose theoretical basis and proof was demonstrated by Ramamoorthy et al., (2009). For that purpose, study was undertaken two consecutive years with increase the production potential and economic analysis of groundnut based cropping systems.

\section{Materials and Methods}

A field experiment was carried out during 2011-12 and 2012-13 at MPKV, Rahuri (M.S.) on sandy clay loam soil with low in available nitrogen $\left(172.11 \mathrm{~kg} \mathrm{ha}^{-1}\right)$, medium in available phosphorus (18.02 $\left.\mathrm{kg} \mathrm{ha}^{-1}\right)$ and high in available potassium (427.0 $\left.\mathrm{kg} \mathrm{ha}^{-1}\right)$ and moderate in Fe $\left(6.89 \mu \mathrm{g} \mathrm{g}^{-1}\right.$ soil $), \mathrm{Mn}(9.51 \mu \mathrm{g}$ $\mathrm{g}^{-1}$ soil $), \mathrm{Zn}\left(0.62 \mu \mathrm{g} \mathrm{g}^{-1}\right.$ soil $)$ and $\mathrm{Cu}(3.41 \mu \mathrm{g}$ $\mathrm{g}^{-1}$ soil). The soil was moderately alkaline in reaction ( $\mathrm{pH} 8.2$ ). The electrical conductivity, 
organic carbon and $\mathrm{CaCO}_{3}$ were $0.29 \mathrm{dSm}^{-1}$, 0.54 and $4.50 \%$, respectively.

The treatment consist of three cropping systems viz., $\mathrm{C}_{1}$-groundnut-onion, $\mathrm{C}_{2}$ groundnut-wheat and $\mathrm{C}_{3^{-}}$groundnut-chickpea with four nutrient management treatments viz., $\mathrm{T}_{1^{-}}$recommended dose of fertilizer, $\mathrm{T}_{1^{-}}$ fertilizer dose as per soil test, $\mathrm{T}_{1^{-}}$fertilizer dose as per STCR equations and control as main plot treatment whereas three fertilizer levels viz., $\mathrm{F}_{1}-100 \% \mathrm{RDF}, \mathrm{F}_{2}-75 \% \mathrm{RDF}$ and $\mathrm{F}_{3^{-}}-50 \% \mathrm{RDF}$ as sub plot treatments. The experiment was laid out in a strip plot design with three replications. Groundnut JL- 501, onion N 2-4-1, wheat- Trimbak and chickpeaDigvijay these cultivators were used during kharif and rabi seasons, respectively. Both the year's crop seasons were favourable to grow the kharif and rabi crops. For comparison between crop sequences, the yields of all crops were converted groundnut equivalent on price basis. The production efficiency value in terms of $\mathrm{kg} \mathrm{ha}^{-1} \mathrm{day}^{-1}$ was calculated dividing the production of the sequence by total duration of sequence and economic efficiency in terms of Rs. ha ${ }^{-1}$ day $^{-1}$ was obtained by net return of sequence divided by total duration of sequence (Kumpawat, 2001). The recommended packages of practices were adopted to grow the crops and fertilizers were applied as per treatments.

\section{Results and Discussion}

\section{Production potential of $\boldsymbol{k h a r i f}$ crop}

Application of fertilizer as per STCR equation to kharif groundnut recorded maximum and significantly higher dry pod yield (23.08 and $24.49 \mathrm{q} \mathrm{ha}^{-1}$ ) than rest of treatments during first year and second year. The yield target of $25 \mathrm{q} \mathrm{ha}^{-1}$ was achieved by STCR equation with less than $10 \%$ variation. The fertilizer dose as per soil test was found second best treatment (18.91 and $19.59 \mathrm{q} \mathrm{ha}^{-1}$ ) during both years experimentation (Table 1). This is because of the balanced nutrition through yield target approach increases the photosynthetic rate and translocation of photosynthates towards reproductive parts of groundnut (pods). Similarly, the groundnut being a legume crop having more nitrate reductase activities in root which is beneficial for peg formation and pod development stage. These results are in conformity with the results obtained by Dudhatra et al., (2002) and Varalakshmi et al., (2005).

\section{Production potential of Rabi crops}

\section{Onion}

Data presented in Table 1, indicated that application of fertilizer as per STCR equation to preceding crop kharif groundnut registered maximum and significantly higher yield of onion bulb (58.85 and $60.67 \mathrm{t} \mathrm{ha}^{-1}$ ) and it was 10.26 and $8.90 \%$ higher than recommended dose of fertilizer during first year and second year. Application of fertilizer as per soil test was found in second rank (54.86 and $56.52 \mathrm{t}$ $\mathrm{ha}^{-1}$ ).

Application of higher level of fertilizer (100\% RDF) to succeeding onion crop preceded by kharif groundnut registered significantly higher bulb yield (48.03 and $49.75 \mathrm{t} \mathrm{ha}^{-1}$ ) and it was 4.52 and 4.38 per cent higher than $75 \%$ recommended dose of fertilizer and it was 15.45 and $17.80 \%$ higher than $50 \%$ recommended dose of fertilizer during first year and second year (Table 2). This might be because of the residual effect of preceding crop maintaining soil organic matter, major and micronutrients, which increases the uptake of these nutrients and accelerating the physiological activities in crop for improving growth attributes. Similarly, it was also increases the translocation of photosynthates towards onion bulb resulted in increasing the size (polar and equatorial diameter) and 
weight of bulb. These results are in conformity with those reported by Konde (2002), Reddy and Suresh (2009) and Jat et al., (2011).

\section{Wheat}

Application of fertilizer as per STCR equation to preceding crop kharif groundnut recorded significantly higher grain yield (42.13 and $43.11 \mathrm{q} \mathrm{ha}^{-1}$ ) of wheat and it was 7.91 and $8.64 \%$ higher than recommended dose of fertilizer on 2011-12 and 2012-13 (Table1).

Application of $100 \%$ recommended dose of fertilizer to wheat crop during rabi season recorded significantly maximum grain yield (35.98 and $36.82 \mathrm{q} \mathrm{ha}^{-1}$ ) and it was 16.40 and $13.32 \%$ higher in $\mathrm{I}^{\text {st }}$ and $\mathrm{II}^{\text {nd }}$ year than reduced level of fertilizer i.e. $50 \%$ recommended dose of fertilizer but at par with $75 \%$ recommended dose of fertilizer during both years. This indicate that growing of wheat crop after kharif groundnut saves $25 \%$ recommended dose of fertilizer because of balance nutrition to kharif groundnut through STCR equation creates favourable environment in the root rhizosphere of wheat crop to absorb more nutrients and moisture by improving the nutrient use efficiency. These results are in corroborated with Verma et al., (2005), Ramesh et al., (2009) and Mubarak and Singh (2011).

\section{Chickpea}

Application of fertilizer as per STCR equation to preceding crop kharif groundnut recorded significantly maximum grain yield of chickpea (28.62 and $29.28 \mathrm{q} \mathrm{ha}^{-1}$ ) than rest of treatments during the period of investigation, however it was at par with fertilizer dose as per soil test during second year of experimentation.

Application of $100 \%$ recommended dose of fertilizer to chickpea during rabi season recorded significantly maximum grain yield
(26.41 and $26.49 \mathrm{qha}^{-1}$ ) and it was 29.27 and $25.30 \%$ higher grain yield than $50 \%$ recommended dose of fertilizer during first year and second year, respectively. However, it was at par with 75 per cent recommended dose of fertilizer in respect of grain yield during both year of experiment (Table 1). This might be because of beneficial residual effect of kharif groundnut by fixing the atmospheric nitrogen through biological means and which may be available to mineralization of plant residues there by increases the yield of succeeding crop. These results are in accordance with Rao and Shakatwat (2002), Ramesh et al., (2009) and Singh et al., (2010).

\section{Total system productivity}

The total system productivity of cropping systems was assessed based on groundnut equivalent yield in groundnut-onion, groundnut-wheat and groundnut-chickpea cropping systems. Among the cropping systems, groundnut-onion cropping system recorded significantly maximum total system productivity of 67.21 and $89.17 \mathrm{q} \mathrm{ha}^{-1}$ and it was 115.48 and $160.12 \%$ higher than groundnut-wheat and 68.19 and 116.43 per cent higher than groundnut-chickpea during first year and second year (Table 2 and Fig. 1).

The nutrient management as per STCR equation proved it's superiority by recording maximum total system productivity of 60.91 and $72.86 \mathrm{q} \mathrm{ha}^{-1}$ and it was followed by nutrient management as per soil test during both years.

The total system productivity was significantly higher with $100 \%$ recommended dose of fertilizer to succeeding crop during rabi season and at par with $75 \%$ recommended dose of fertilizer during both the years. These results are in accordance with Ramesh et al., (2009), Jat et al., (2011), and Mukundam et al., (2012). 
Table.1 Yield of component crops in different cropping systems as influenced by different treatments

\begin{tabular}{|c|c|c|c|c|c|c|c|c|}
\hline \multirow[t]{2}{*}{ Treatment } & \multicolumn{2}{|c|}{$\begin{array}{l}\text { Groundnut pod yield (q } \\
\text { ha- }^{1} \text { ) }\end{array}$} & \multicolumn{2}{|c|}{$\begin{array}{l}\text { Onion bulb yield } \\
\left(\mathrm{t} \mathrm{ha}^{-1}\right)\end{array}$} & \multicolumn{2}{|c|}{$\begin{array}{l}\text { Wheat grain yield } \\
\left(\mathrm{g} \text { ha- }^{-1}\right)\end{array}$} & \multicolumn{2}{|c|}{$\begin{array}{c}\text { Chickpea grain yield (q } \\
\text { ha-1 }^{1} \text { ) }\end{array}$} \\
\hline & 2011-12 & 2012-13 & 2011-12 & 2012-13 & 2011-12 & $2012-13$ & 2011-12 & $2012-13$ \\
\hline $\begin{array}{l}\text { Nutrient management }(T) \\
T_{1} \text {-Recommended dose of fertilizer } \\
T_{2}-\text { Fertilizer dose as per soil test } \\
\mathrm{T}_{3} \text { - Fertilizer dose as per STCR eq }{ }^{\mathrm{n}}\left(25 \mathrm{qha}^{-1}\right) \\
\mathrm{T}_{4} \text {-Control (No fertilizer) } \\
\text { SEm } \pm \\
\text { C.D. }(0.05)\end{array}$ & $\begin{array}{c}16.43 \\
18.91 \\
23.08 \\
7.96 \\
0.59 \\
1.71\end{array}$ & $\begin{array}{c}17.61 \\
19.59 \\
24.49 \\
6.63 \\
0.52 \\
1.54\end{array}$ & $\begin{array}{c}53.37 \\
54.86 \\
58.85 \\
13.68 \\
0.76 \\
2.64\end{array}$ & $\begin{array}{c}55.71 \\
56.52 \\
60.67 \\
13.28 \\
0.82 \\
2.83\end{array}$ & $\begin{array}{c}39.04 \\
40.15 \\
42.13 \\
13.47 \\
0.26 \\
0.91\end{array}$ & $\begin{array}{c}39.68 \\
41.49 \\
43.11 \\
12.66 \\
0.38 \\
1.33\end{array}$ & $\begin{array}{c}25.64 \\
26.37 \\
28.62 \\
14.01 \\
0.27 \\
0.95\end{array}$ & $\begin{array}{c}26.34 \\
27.43 \\
29.28 \\
13.06 \\
0.59 \\
2.05\end{array}$ \\
\hline $\begin{array}{l}\text { B. Fertilizer levels }(\mathrm{F}) \\
\mathrm{F}_{1}-100 \% \text { of RDF } \\
\mathrm{F}_{2}-\mathbf{7 5} \% \text { of RDF } \\
\mathrm{F}_{3}-50 \% \text { of RDF } \\
\text { SEm } \pm \\
\text { C.D. }(0.05)\end{array}$ & $\begin{array}{l}-- \\
-- \\
-- \\
-- \\
--\end{array}$ & $\begin{array}{l}-- \\
-- \\
-- \\
--\end{array}$ & $\begin{array}{c}48.03 \\
45.95 \\
41.60 \\
0.52 \\
2.05\end{array}$ & $\begin{array}{c}49.75 \\
47.66 \\
42.23 \\
0.68 \\
2.65\end{array}$ & $\begin{array}{c}35.98 \\
34.21 \\
30.91 \\
0.39 \\
1.54\end{array}$ & $\begin{array}{c}36.82 \\
35.41 \\
32.49 \\
0.46 \\
1.79\end{array}$ & $\begin{array}{c}26.41 \\
24.15 \\
20.43 \\
0.37 \\
1.46\end{array}$ & $\begin{array}{c}26.49 \\
24.46 \\
21.14 \\
0.36 \\
1.42\end{array}$ \\
\hline
\end{tabular}

Table.2 The productivity of different cropping systems as influenced by different treatments

\begin{tabular}{|c|c|c|c|c|c|c|}
\hline \multirow[t]{2}{*}{ Treatment } & \multicolumn{2}{|c|}{$\begin{array}{l}\text { Total system } \\
\text { productivity }\left(\mathbf{q} \mathbf{h a}^{-1}\right)\end{array}$} & \multicolumn{2}{|c|}{$\begin{array}{l}\text { Production efficiency } \\
\left(\mathrm{kg} \mathrm{ha}^{-1} \mathbf{d a y}^{-1}\right)\end{array}$} & \multicolumn{2}{|c|}{$\begin{array}{l}\text { Economic efficiency } \\
\left(\text { Rs. }^{-1} \mathbf{d a y}^{-1}\right)\end{array}$} \\
\hline & 2011-12 & $2012-13$ & 2011-12 & 2012-13 & 2011-12 & 2012-13 \\
\hline \multicolumn{7}{|l|}{ A. Cropping system (C) } \\
\hline $\mathrm{C}_{1}$ - Groundnut-onion & 67.21 & 89.17 & 30.16 & 39.96 & 620.66 & 1064.26 \\
\hline $\mathrm{C}_{2^{-}}$Groundnut-wheat & 31.19 & 34.28 & 14.34 & 15.67 & 166.09 & 252.63 \\
\hline $\mathrm{C}_{3}$ - Groundnut-chickpea & 39.96 & 41.20 & 18.94 & 19.61 & 327.32 & 399.66 \\
\hline SEm + & 0.39 & 0.56 & 0.18 & 0.26 & 6.68 & 9.66 \\
\hline $\mathrm{CD}(\overline{0.05)}$ & 1.14 & 1.66 & 0.53 & 0.75 & 20.13 & 28.35 \\
\hline \multicolumn{7}{|l|}{ B. Nutrient management (T) } \\
\hline$T_{1}$ Recommended dose of fertilizer & 50.32 & 61.85 & 23.17 & 28.45 & 422.98 & 681.73 \\
\hline $\mathrm{T}_{2}-$ Fertilizer dose as per soil test & 53.74 & 64.92 & 24.60 & 29.56 & 474.61 & 721.74 \\
\hline $\mathrm{T}_{3}$ - Fertilizer dose as per STCR eq ${ }^{\mathrm{n}}\left(25 \mathrm{q} \mathrm{ha}^{-1}\right)$ & 60.91 & 72.86 & 27.63 & 32.87 & 578.11 & 848.56 \\
\hline $\mathrm{T}_{4}$-Control (No Fertilizers) & 19.53 & 19.91 & 9.18 & 9.44 & 9.74 & 36.72 \\
\hline $\mathrm{SEm}+$ & 0.45 & 0.65 & 0.21 & 0.29 & 7.92 & 11.15 \\
\hline C.D. $(\mathbf{0 . 0 5})$ & 1.32 & 1.92 & 0.61 & 0.87 & 23.25 & 32.73 \\
\hline \multicolumn{7}{|l|}{ C. Fertilizer levels (F) } \\
\hline$F_{1} .100 \%$ of RDF & 47.68 & 57.18 & 21.84 & 26.40 & 391.75 & 607.80 \\
\hline$F_{2} .75 \%$ of RDF & 47.12 & 56.40 & 21.61 & 25.49 & 386.92 & 597.72 \\
\hline $\mathrm{F}_{3} .50 \%$ of RDF & 43.58 & 51.07 & 19.99 & 23.34 & 335.41 & 511.04 \\
\hline SEm + & 0.44 & 0.33 & 0.20 & 0.32 & 6.94 & 5.65 \\
\hline C.D. $(0.05)$ & 1.25 & 0.94 & 0.57 & 0.95 & 19.76 & 16.08 \\
\hline
\end{tabular}


Table.3 Economics of different cropping systems as influenced by different treatments

\begin{tabular}{|c|c|c|c|c|c|c|c|c|}
\hline Treatment & \multicolumn{2}{|c|}{$\begin{array}{l}\text { Gross monetary } \\
\left.\text { returns (Rs. ha }{ }^{-1}\right)\end{array}$} & \multicolumn{2}{|c|}{$\begin{array}{c}\text { Cost of } \\
\text { cultivation } \\
\left(\text { Rs. ha } \mathbf{h}^{-1}\right)\end{array}$} & \multicolumn{2}{|c|}{$\begin{array}{c}\text { Net monetary } \\
\text { returns } \\
\left(\text { Rs. ha }{ }^{-1}\right)\end{array}$} & \multicolumn{2}{|c|}{ B:C ratio } \\
\hline \multicolumn{9}{|l|}{ A. Cropping system (C) } \\
\hline $\mathrm{C}_{3^{-}}$Groundnut-chickpea & 137887 & 154535 & 67769 & 70252 & 70118 & 84282 & 2.05 & 2.16 \\
\hline $\mathrm{SE} \mathbf{m} \pm$ & 1349 & 2130 & ---- & --- & 1349 & 2129 & --- & --- \\
\hline $\mathrm{CD}(\mathbf{0 . 0 5})$ & 3960 & 6248 & ---- & --- & 3958 & 6247 & --- & --- \\
\hline \multicolumn{9}{|l|}{ B. Nutrient management (T) } \\
\hline $\mathrm{SE} \mathbf{m} \pm$ & 1558 & 2459 & ---- & ---- & 1558 & 2458 & ---- & ---- \\
\hline C.D. $(\overline{0.05})$ & 4573 & 7215 & ---- & ---- & 4570 & 7213 & ---- & ---- \\
\hline \multicolumn{9}{|l|}{ C. Fertilizer levels (F) } \\
\hline $\mathrm{F}_{1 .} \mathbf{1 0 0 \%}$ of RDF & 164493 & 214458 & 78401 & 80769 & 86092 & 133688 & 2.10 & 2.65 \\
\hline $\mathrm{F}_{2 .} \mathbf{7 5} \%$ of $\mathrm{RDF}$ & 162564 & 211504 & 77540 & 79890 & 85023 & 131614 & 2.09 & 2.64 \\
\hline $\mathrm{F}_{3-} \mathbf{5 0} \%$ of RDF & 150355 & 191531 & 76680 & 79011 & 73674 & 112519 & 1.96 & 2.42 \\
\hline $\mathrm{SE} \mathbf{m} \pm$ & 1519 & 1241 & --- & ---- & 1519 & 2198 & ---- & ---- \\
\hline C.D. $(\overline{0.05})$ & 4322 & 3530 & --- & --- & 4322 & 6594 & --- & ---- \\
\hline
\end{tabular}


Table.4 Details of prices used for economic evaluation

\begin{tabular}{|c|c|c|c|}
\hline \multirow{2}{*}{$\begin{array}{l}\text { Sr. } \\
\text { No. }\end{array}$} & \multirow[t]{2}{*}{ Particulars } & \multicolumn{2}{|c|}{ Prices } \\
\hline & & 2011-12 & 2012-13 \\
\hline 1 & Ploughing (Rs. ha ${ }^{-1)}$ & 2500.00 & 2500.00 \\
\hline 2 & Rotavator $\left(\right.$ Rs. ha $\left.^{-1}\right)$ & 2250.00 & 2250.00 \\
\hline 3 & Labour charges (Rs. ha ${ }^{-1}$ head $^{-1}$ ) & 146.00 & 149.00 \\
\hline$\overline{4}$ & Cost of seed (Rs. $\mathrm{kg}^{-1)}$ & & \\
\hline $\bar{i}$ & Groundnut & 87.00 & 88.00 \\
\hline ii & Onion & 1000.00 & 1000.00 \\
\hline iii & Wheat & 22.00 & 25.75 \\
\hline IV & Chickpea & 22.50 & 51.00 \\
\hline 5 & Cost of chemical fertilizers (Rs. $\mathrm{kg}^{-1)}$ & & \\
\hline$\overline{\mathbf{i}}$ & Urea & 5.62 & 5.62 \\
\hline ii & Single super phosphate & 7.40 & 7.40 \\
\hline Iii & Muriate of potash & 17.80 & 17.80 \\
\hline iv & Di ammonium phosphate & 16.80 & 23.66 \\
\hline 6 & Cost of biofertilizer and biopesticide (Rs. $\mathrm{kg}^{-1)}$ & & \\
\hline $\mathbf{i}$ & Azatobacter & 40.00 & 40.00 \\
\hline ii & PSB & 60.00 & 60.00 \\
\hline iii & Rhizobium & 40.00 & 40.00 \\
\hline iv & Trichoderma & 150.00 & 150.00 \\
\hline 7 & Farm yard manure (Rs. $t^{-1)}$ & 1200.00 & 1200.00 \\
\hline 8 & Insecticide and pesticides (Rs. $\mathrm{L}^{-1,} \mathrm{~kg}^{-1}$ ) & & \\
\hline $\mathbf{i}$ & $50 \%$ WP Carbendezium (Bavistin) & 1160.00 & 1160.00 \\
\hline ii & Tebuconozole $25.9 \%$ EC (Folicur) & 1700.00 & 1700.00 \\
\hline iii & $50 \%$ EC Prophenophos (Curacron) & 430.00 & 430.00 \\
\hline iv & Chloropyriphos $20 \% \mathrm{EC}$ & 330.00 & 400.00 \\
\hline $\mathbf{v}$ & Imidachloprid@17.8\% (Confidor) & 1500.00 & 1944.00 \\
\hline 9 & Irrigation Charges (Rs. ha ${ }^{-1}$ turn $^{-1)}$ & 400.00 & 400.00 \\
\hline$\overline{10}$ & Land rent(Rs.ha ${ }^{-1}$ year $\left.^{-1}\right)$ & 225.00 & 225.00 \\
\hline 11 & Selling rate of Main produce (Rs.q ${ }^{-1)}$ & & \\
\hline $\bar{i}$ & Groundnut & 3450.00 & 3750.00 \\
\hline ii & Wheat & 1400.00 & 1800.00 \\
\hline iii & Chickpea & 3300.00 & 3600.00 \\
\hline iv & Onion & 360.00 & 600.00 \\
\hline 12 & By produce (Rs. $\left.q^{-1}\right)$ & & \\
\hline $\bar{i}$ & Groundnut haulm & 55.00 & 100.00 \\
\hline ii & Wheat straw & 20.00 & 30.00 \\
\hline iii & Chickpea straw & 60.00 & 100.00 \\
\hline
\end{tabular}




\section{Production efficiency}

Among the cropping systems, groundnutonion cropping system registered significantly higher production efficiency (30.16 and 39.96 $\mathrm{kg} \mathrm{ha} \mathrm{d}^{-1} \mathrm{day}^{-1}$ ) than groundnut-wheat and groundnut-chickpea cropping systems during both the years of experimentation. The groundnut-wheat cropping system registered significantly lowest on production efficiency (14.34 and $15.67 \mathrm{~kg} \mathrm{ha}^{-1} \mathrm{day}^{-1}$ ) during both the years.

The nutrient management treatments as per STCR equation registered significantly higher production efficiency of 27.63 and $32.87 \mathrm{~kg}$ $\mathrm{ha}^{-1}$ day $^{-1}$ and it was 19.24 and $15.53 \%$ higher than recommended dose of fertilizer during first year and second year.

Application of $100 \%$ recommended dose of fertilizer to succeeding crop during rabi season registered significantly higher production efficiency $(21.84,26.40$ and 24.12 $\mathrm{kg} \mathrm{ha}^{-1} \mathrm{day}^{-1}$ ) than $50 \%$ recommended dose of fertilizer and at pat with $75 \%$ recommended dose of fertilizer during both the years (Table 2 and Fig. 2).

Similar findings were postulated by Srinivas and Srinivasa Raju (2000), Walia et al., (2009) and Jat (2011).

\section{Economic efficiency}

The groundnut-onion cropping system recorded significantly higher economic efficiency (Rs. 620.66 and $1064.26 \mathrm{ha}^{-1}$ day $^{-1}$ ) than groundnut-wheat (Rs.166.09 and 252.63 ha $^{-1}$ day $^{-1}$ ) and groundnut-chickpea (Rs. 327.32 and $399.66 \mathrm{ha}^{-1}$ day $^{-1}$ ) cropping systems during both the years.

Application of fertilizer as per STCR equation to kharif groundnut recorded significantly higher economic efficiency (Rs.578.11 and
$848.56 \mathrm{ha}^{-1} \mathrm{day}^{-1}$ ) than rest of the nutrient management and control treatment during both the years. The control treatment registered significantly lowest economic efficiency (Rs. 9.74 and 36.72 ha $^{-1}$ day $^{-1}$ ) during both the years.

The economic efficiency of different cropping systems was also influenced by different fertilizer levels. Application of $100 \%$ recommended dose of fertilizer to succeeding crop during rabi season recorded significantly higher economic efficiency (Rs. 391.75 and $607.80 \mathrm{ha}^{-1}$ day $^{-1}$ ) than $50 \%$ recommended dose of fertilizer level (Rs. 335.41 and 511.04 $\mathrm{ha}^{-1}$ day $^{-1}$ ) and it was as par with $75 \%$ recommended dose of fertilizer (Rs. 386.92 and $597.72 \mathrm{ha}^{-1}$ day $^{-1}$ ) during both years (Table 2 and Fig. 3). This is because of higher yield and biomass production with higher level of fertilizer. These results are in agreement with Walia et al., (2009), Jat et al., (2011) and Singh et al., (2012).

\section{Economic analysis}

Among the cropping systems, groundnutonion cropping system obtained significantly maximum gross monetary returns (Rs. 2,31,903 and Rs. 3,34,409 ha ${ }^{-1}$ ), net monetary returns (Rs. 1,38,207 and Rs. 2,37,982 $\mathrm{ha}^{-1}$ ) and $\mathrm{B}: \mathrm{C}$ ratio (2.48 and 3.47) than groundnutwheat and groundnut-chickpea cropping systems during both the years.

The groundnut-chickpea cropping system was found second rank in respect of gross and net monetary returns during both the years. Application of fertilizer as per STCR equation to kharif groundnut obtained significantly maximum gross monetary returns (Rs. 2,10,156 and Rs. 2,73,232 ha ${ }^{-1}$ ), net monetary returns (Rs. 1,27,665 and Rs. 1,88,477 ha ${ }^{-1}$ ) and $\mathrm{B}: \mathrm{C}$ ratio (2.58 and 3.22) than rest of the nutrient management treatments during both the years. 
Application of 100 per cent recommended dose of fertilizer to succeeding crop during rabi season obtained significantly maximum gross monetary returns (Rs.1,64,493, and Rs. 2,14,458 $\mathrm{ha}^{-1}$ ), net monetary returns (Rs. 86,092 and Rs. 1,33,688 $\mathrm{ha}^{-1}$ ) and B:C ratio (2.10 and 2.65) than $50 \%$ recommended dose of fertilizer. However, it was at par with $75 \%$ recommended dose of fertilizer in respect of gross monetary returns, net monetary returns and $\mathrm{B}$ : $\mathrm{C}$ ratio during both the years (Table 3 and 4). These results are in conformity with those reported by Walia et al., (2009), Jat et al., (2011) and Mukundam et al., (2012)

On the basis of two years of experiment, it could be concluded that, application of fertilizer as per soil test crop response equation to kharif groundnut followed by 75 $\%$ recommended dose of fertilizer (75:37.5:37.5 N, $\left.\mathrm{P}_{2} \mathrm{O}_{5}, \mathrm{~K}_{2} \mathrm{O} \mathrm{kg} \mathrm{ha}{ }^{-1}\right)$ to onion during rabi season found most beneficial to achieve maximum yield and monetary returns in groundnut- onion cropping system.

\section{References}

Dudhatra, M. G., Vaghani, M.N., Kachot, N.A. and Asodaria, K.B. 2002. Integrated input management in groundnut (Arachis hypogaea L.)-wheat (Ttriticum aestivium L.) cropping system. Indian Journal of Agronomy, 47 (4): 482-486.

Jat, R. S., Dayal Devi, Meena, H. N., Singh Virendra and Gedia, M.V. 2011. Long term effect of nutrient management and rainfall on pod yield of groundnut (Arachis hypogea L.) in groundnut based cropping systems. Indian Journal of Agronomy, 56 (2): 145-149.

Konde, N. M. 2002. Fertilizer requirement of soybean-wheat cropping system by conjoint use of manure and chemical fertilizers based on targeted yield approach. Ph.D. Thesis submitted to the M.P.K.V., Rahuri (M.S.)
Kumpawat, B.S. 2001. Production potential and economics of different crop sequences. Indian Journal of Agronomy, 46 (3): 421-424.

Mubarak, T and Singh, K. N. 2011. Nutrient management and productivity of wheat (Triticum aestivum L.) based cropping systems in temperate zone. Indian Journal of Agronomy, 56 (3): 176-181.

Mukundam, B., Yakadari, M., Raja, V. and Srividya, S. 2012. Diversification of rice (Oryza sativa L.) based cropping systems for improving productivity and income in Telengana region of Andhra Pradesh. Indian Journal of Agronomy, 57 (1): 20-23.

Ramamoorthy, K., Radhamani, S., Mohamed Amanullah, M. and Subbiah, P. 2009. Role of food legumes in organic farming. Green Farming., 2 (12): 830834.

Ramesh, P. Panwar, N.R., Singh A.B. and Ramana, S. 2009. Production potential, nutrients uptake, soils fertility and economics of soybean (Glycine max L.)-based cropping systems under organic chemical and integrated nutrient management practices. Indian Journal of Agronomy, 54 (3): 278-283.

Rao, S.S. and Shaktawat M.S. 2002. Residual effect of organic manure, phosphorus and gypsum application in preceding groundnut (Archis hypogaea L.) on soil fertility and productivity of Indian mustard (Brassica juncea L.) Indian Journal of Agronomy, 47(4): 487-494.

Reddy, B.N. and Suresh, G. 2009. Crop diversification with oilseed crops for maximizing productivity, profitability and resource conservation. Indian Journal of Agronomy, 54 (2): 206-214.

Singh R. A., Singh, I.P. and Haider, E. 2010. Balanced nutrition of chickpea in groundnut-chickpea cropping system. International Journal of Agriultural Sciences 6 (2): 590-591. 
Singh, J.P., Salaria, A. and Gangawat, B. 2012. Efficiency of diversified ricewheat cropping systems including potato, vegetable peas and groundnut crops in transgangetic plains. Indian Journal. com. 53-60.

Srinivas, A. and Srinivasa Raju, M.2000. Studies on groundnut (Arachis hypogea L.) based cropping system in Andhra Pradesh. Journal of Oilseeds Research 17 (1): 77-81.

Varalakshmi, L. R., Srinivasamurthy, C. A. and Bhaskar, S. 2005. Effect of integrated use of organic manures and inorganic fertilizers on organic carbon, available $\mathrm{N}, \mathrm{P}$ and $\mathrm{K}$ in sustaining productivity of groundnut-finger millet cropping system. Journal of Indian Society of Soil Science, 53 (3): 315-318.

Verma, A., Nepalia, V. and Kanthaliya, P. C. 2005. Effect of continuous cropping and fertilization on crop yields and nutrient status of a Typic Haplustept. Journal of Indian Society of Soil Science, 53 (3): 365-368

Walia, S.S., Gill, M.S., Dhaliwal, S.S. and Phutela, R. P. 2009. Evaluation of different cropping systems for increased yields, water productivity and profitability in Punjab. Journal of Punjab Agricultural Universities, 46 (3 and 4): 131-136.

\section{How to cite this article:}

Pacharne, D.P. and Deshmukh, P.H. 2018. Economic Analysis of Groundnut Based Cropping Systems. Int.J.Curr.Microbiol.App.Sci. 7(09): 2876-2884.

doi: https://doi.org/10.20546/ijcmas.2018.709.357 